\title{
Thinking Feeling at the Dickens Bicentenary
}

\section{Gail Marshall, Ian Higgins, Catherine Malcolmson, Kris Siefken, Holly Furneaux}

Dickens 2012 has been characterized by heartfelt responses to Dickens. In the 'think pieces' that follow, a number of scholars of Dickens and the Victorian period from the Victorian Studies Centre at the University of Leicester ruminate on the inflections of bicentenary feeling: What are the politics, and aesthetics, of Dickensian feeling? How close are these to Dickens's expressed aspirations for his work? Are there continuities with Victorian responses, and those at the 1912 centenary? Where is 2012 sentiment located culturally and nationally? How are feelings other than celebration registered and expressed? The short pieces that follow seek to open up these questions in a way that will, we hope, encourage further response and discussion.

\section{Dickens 2012}

\section{Gail Marshall}

2012 has the feel of an iconic year. Its alliterative qualities roll off the tongue in a selfconfirming way that signals its specialness. It's an Olympic year; a Diamond Jubilee year; and it is Dickens's year. All invite comparisons with the nineteenth century.

The Olympics perhaps come as near as it is possible to get in our modern world to the international buzz of the Crystal Palace exhibition, to the sense of nations gathering to exhibit their wares and to assert their prowess - albeit on the sports fields, pools, rings, and velodromes of the modern games rather than in an exhibition of arts and technology. Queen Elizabeth's Jubilee has generated comparisons with Queen Victoria's, and seems set to resonate throughout the year with implications for modern Britain's sense of itself. Queen Elizabeth's first Jubilee visit of the year has been to Leicester, one of the most harmoniously multicultural cities in England. And Dickens has, it seems, been everywhere. There have been numerous celebrations, some of which are dealt with in more detail later in this round-table discussion. They range from $\mathrm{BBC}$ radio and television specials, a service at Westminster Abbey, a reception at Buckingham Palace for leading Dickensians from around the world, the launch of the superb Dickens Journals Online project under the guiding hand of John Drew at the University of Buckingham, and 
numerous reading projects designed to take new and old readers back to the novels with fresh eyes.

All three forms of commemoration have been mutually informing in the public eye, inasmuch as they all speak to some of the enormous variety of ways in which we construct national identity. Dickens has been embraced by newspapers across the political spectrum as having something to say to current readers. He has been welcomed by church leaders as a still resonant voice to champion the needy, and has been the subject of TV documentaries which speak to pressing aspects of contemporary cultural identity. Sue Perkins's Mrs Dickens' Family Christmas was an enjoyable demystification of the persona of Dickens the devoted family man for a general audience. While keen to take an idol down a peg or two, the programme also spoke to a tendency to want to open up to greater scrutiny the myth of the Victorians, and our sense of indebtedness to their period. Armando Iannucci's Armando's Tale of Charles Dickens aimed to reclaim Dickens for readers as opposed to academics, an opposition that few academics would recognize, and went on to perform some beautiful close readings that would have been as much at home in a seminar room as on the TV. The BBC billed the programme as showing the aspects of Dickens's work 'which make him worth reading, as much for what he tells us about ourselves in the twenty-first century as our ancestors in the nineteenth'. Diverse in approach, these two programmes nonetheless speak to the common cultural currency of Dickens which the year's events affirm.

But in what is that sense of currency, of continuity, embedded? Surely not just in our general fascination with the Victorians? As an Eliot scholar, I am already anxious that the celebrations of her bicentenary in 2019 will be on nothing like the scale Dickens is enjoying, and Thackeray's bicentenary last year went practically unnoticed outside academic circles. Both are crucially important writers, but neither has achieved the general popularity of Dickens, perhaps because neither appeals so self-consciously to the sentiment of their readers, to an emotional responsiveness that has proved irresistible over the years, and to which audiences respond readily, warmly, and collectively. Each of this year's celebrations has its detractors and sceptics, but each also provides a node around which communities will cluster and develop. 


\section{'Such community of feeling': Dickens and Bicentenary Sentiment}

\section{Ian Higgins}

What would Charles Dickens, an author who so relished popular acclaim, have made of the 2012 bicentenary celebrations in his honour? Looking at a comparable event in his own time, Shakespeare's tercentenary in 1864, leaves one with the impression that Dickens (described in 1841 as 'the living Shakespeare') was actually less than enthusiastic about such celebrations. ${ }^{2}$ Although he visited Stratford-upon-Avon with John Forster, Wilkie Collins, and Robert Browning on 23 April 1864, an article in All the Year Round a year later described the tercentenary as a 'lamentable failure'. ${ }^{3}$ In another article, 'Shakespeare-Mad', published a month after the April celebrations, the writer gave his reason for this dislike, complaining that the festivities themselves had nothing really to do with Shakespeare's character or works: 'that honour to the Bard had much to do with the celebration, I will not pretend to declare'.

However, although Stratford's fireworks display and masked ball were 'depressing', Dickens found more to admire in the emotional response of a company of Shakespeare enthusiasts gathered together, 'all classes and degrees mingling on equal terms of brotherhood in honour of the great High Priest of their art'. He goes on:

Ah, surely he was a Great Magician, whose name, after three centuries, could work such a charm. It was good for the heart to see such community of feeling. ${ }^{5}$

Dickens clearly approved of the genuinely felt response to this 'Great Magician', over the vanity of the commemorative verses he disliked so much (at Stratford he was amused by a poem which began 'Come let us tercenterate', and he mockingly includes a 'Poem on Shakespeare' among the dinner guests at the Veneerings' table in Our Mutual Friend $(1864-65)){ }^{6}$

Has the 2012 bicentenary celebration then shown 'such community of feeling' as the 'Inimitable' might have approved of himself? Across different kinds of media, the general tone has been one of personal, emotional response. The Telegraph newspaper ran a series in which a number of its journalists wrote a piece about their favourite Dickens characters, while Penguin Books posted a similar poll on its website, with Ebenezer Scrooge taking first place. On the BBC, as Gail Marshall discusses above, two prominent non-dramatic programmes on Dickens, Mrs Dickens' Family Christmas by Sue Perkins 
and Armando's Tale of Charles Dickens by Armando Iannucci, were based on the very personal responses of each programme's host. Iannucci's broadcast took the form of a 'personal argument' based on his being a 'lifelong fan' of Dickens's humour, in which he argued against the idea of Dickens as a 'national institution', seeing him instead as 'the funniest comedian we've ever produced' ${ }^{7}$ In publishing, meanwhile, Simon Callow's very personal take on the life in Charles Dickens and the Great Theatre of the World was accompanied by an article in the bicentenary week entitled 'My Hero', which included this appreciation: 'From the moment [Dickens] started to write, he spoke for the people, and the people loved him for it, as do I., ${ }^{8}$

However, this is not to say that the emotional response to Dickens is a simple or one-dimensional matter, that such 'community' of feeling necessarily implies a unity of feeling. On the contrary, Dickens's emotional 'power' remains rich in polemical potential, as demonstrated by the way in which the language of the 'Dickensian' has been used as emotional capital in political journalism around the time of the bicentenary celebrations. This is especially the case in relation to hot social topics such as austerity measures, welfare cuts, and education. In an article entitled 'The Coalition's Dickensian Take on Disability Allowance', for example, the novelist Clare Allan criticizes the coalition government for 'embark[ing] upon a wholesale reconstruction of Dickensian society':

Housing, education, health, social welfare; everything we have put together since, in order to protect the most vulnerable, is in the process of being dismantled [...]. It is hard to read the details of the welfare reform bill [...] being debated in parliament, without picturing Dickens rolling his eyes in dismay. ${ }^{9}$

Martin Rowson's cartoon in the 7 February edition of the same paper similarly employed the idea of the 'Dickensian' as shorthand for social inequality, and implied moral outrage at it. The drawing shows a grimy, gaslit street in which the Secretary of State for Work and Pensions Iain Duncan Smith, dressed as a Victorian gentleman, walks past a crowd of impoverished men and women. David Cameron peers out of a window, and two speech bubbles express the conversation: 'Splendid idea to celebrate Dickens' bicentenary with this Dickensian re-enactment!' 'What Dickensian re-enactment?' ${ }^{10}$ Meanwhile, Allison Pearson in the Telegraph of 8 February used the bicentenary to lament the 'devastating decline in literacy' and the unlikelihood of school children actually reading any Dickens:

They may be rereading Dickens in the book-lined salons of literary London, but out in the world, the dank, fog-licked world where Pip and Davey and 
Oliver came from, they barely know who dear Mr Dickens is, and they sure as hell aren't reading him. For they can barely read. ${ }^{11}$

It is hard not to agree with Peter Conrad that "the nation currently fancies that Dickens is its lost liberal conscience'. ${ }^{12}$

\section{'Our love and gratitude should be displayed': Expressing Feeling in 1912 and 2012 Catherine Malcolmson}

February $7^{\text {th }} 1912$, has come and gone, and no one was allowed to be in ignorance of the fact that it was the centenary of Dickens's birth, for every newspaper placard blazoned it forth in bold letters, and every newspaper emphasised the fact in column after column of eulogy. ${ }^{13}$

Reading this comment in the Dickensian, the journal of the Dickens Fellowship, it is striking how similar this year's bicentenary celebrations of Dickens's birth have been to their 1912 counterpart. Dickens's popularity as an author and cultural figure ensured that both anniversaries have elicited a great deal of media attention. In 2012, the forms of media may have changed, but the sense of celebration was the same. Numerous articles appeared in the press, books on Dickens were published, and television adaptations and documentaries were screened, all drawing attention to the 'bicentenary year'.

While the 1912 centenary undoubtedly provided a considerable marketing opportunity for booksellers and makers of Dickensian memorabilia, the overriding characteristic of the celebrations was the undisguised use of sentiment to encourage the nation to commemorate Dickens's life and works. In an article in the Dickensian, the President of the Dickens Fellowship, J. Cuming Walters, declared that 1911 is 'Our Year of Preparation', reminding Dickensians that

we shall soon be called upon to celebrate reverently and joyously the hundredth anniversary of Charles Dickens's birth [...]. Our love and gratitude should be displayed in no half-hearted way, but with due thought, conscious and steady resolve, fixed purpose. ${ }^{14}$

The spiritual language — 'reverently and joyously' — is often a feature of articles in the Dickensian, but it is notable that the Fellowship regards the centenary celebrations as an expression of their 'love and gratitude' for the author. Their act of commemoration is in tribute to an author who inspires an affective response through his fiction. 
In 2012, we are perhaps more easily embarrassed by this emotional response to Dickens, regarding it as a failure of academic objectivity or critical distance. Yet the centrepiece of Dickens's bicentenary celebrations on 7 February 2012 was a graveside service at Westminster Abbey. Dickens's morality and charity were eulogized by the Archbishop of Canterbury, suggesting that a 'reverent' commemoration is still considered appropriate for Dickens. The choice of reading for the service also highlighted the manner in which shared memories of Dickens are bound up with sentiment. The actor Ralph Fiennes read the account of Jo's death in Bleak House, a passage which is sure to tug at the heartstrings and prompted more than a few tears from the audience. While the Dickensians in 1912 would have considered this show of emotion to be entirely appropriate, in 2012 Dickens's ability to move an audience to tears seems more surprising.

The 1912 celebrations centred around the 'Charles Dickens Testimonial Campaign', an idea put forward by the Strand Magazine, but endorsed by the Dickens Fellowship. This campaign asserted that 'owing to the privileges of a copyright law which Dickens did not live to see', his estate had been denied the advantages of his enduring popularity. The campaign proposed the sale of penny stamps which readers could purchase and affix to their existing copies of Dickens's works, thereby offering the author's descendants a 'deferred royalty'. The appeal was controversial because of questions raised as to the neediness of the author's grandchildren, who stood to benefit. However, the scheme was successful in raising funds by urging contributions from those who felt a debt of 'personal gratitude' to the 'creator of Pickwick and Weller, Tiny Tim and Little Nell' ${ }^{15}$ This list was not arbitrary, but enlisted the Dickens characters held most highly in public affection for either their humour or their pathos.

Alongside this scheme, a Centenary Register was opened in locations around London, permitting readers of Dickens to sign their names and declare: 'We, the admirers of the genius of Charles Dickens, recognizing the great services he rendered by his works to the whole English-speaking race, inscribe our names in this book in grateful testimony on the occasion of his centenary'. ${ }^{16}$ The sentiment here is, again, one of gratitude to a much-loved author. Yet the reference to the 'English-speaking race', a phrase which frequently reoccurs in promotional material for the 1912 centenary, marks the widest gulf between the centenary and bicentenary celebrations.

A key theme of this year's festivities was the idea of a global Dickens: the recognition of a worldwide readership of his novels and a greater awareness of the varied 
and competing meanings which his novels may have in other cultures. The British Council's role in the Dickens 2012 project exemplifies this worldwide readership. The idea of Dickensian city life has been reimagined by young writers in Buenos Aires, and authors have spoken of how they have attempted to reclaim Dickens from the associations of 'Englishness', which are frequently bound up with colonialism. One powerful means by which the British Council gave a voice to this global audience was through a Dickens Read-a-thon. Over a twenty-four-hour period readers from countries around the world used social media to share readings from Dickens's novels. The videos are affecting, perhaps because they highlight the community experience of reading Dickens. Hearing so many voices reading such familiar words gives the viewer a sense of being bound up in a shared experience, an experience of a similar nature to the act of inscribing one's signature in the 1912 Centenary Register. ${ }^{17}$ While both centenary celebrations were a product of their time, each sought to celebrate Dickens's birth collectively through a shared experience of his written work. While the 1912 centenary of Dickens's birth made explicit use of the language of sentiment to provoke an emotional response, the 2012 anniversary demonstrated that reading Dickens collectively still retains an affective power to move us to sentiment.

\section{The Space Between: Thought and Feeling at the Dickens Bicentenary Kris Siefken}

Shortly after the bicentenary, novelist Howard Jacobson remarked, 'Some people are tiring of the Dickens hubbub, but I am not. No praise is too high for him [...], no celebration of his genius excessive'. He went on to suggest 'Dickens' as a form of national genetic inheritance:

$\mathrm{He}$ is in the blood. If we declaim, we declaim Dickensianly. If we delight in the preposterous, it is because Dickens taught us where to find it, how it sounded, how to love its outrageous resourcefulness [...] it is as though he invented us. ${ }^{18}$

Similarly, at the bicentenary ceremony at Westminster Abbey, the Archbishop of Canterbury began his address with this extraordinary passage:

It's difficult to tell the truth about human beings. [...] The truth is extreme, the truth is excessive. The truth about human beings is more grotesque and bizarre than we can imagine. And Dickens' generous embrace of human beings does 
not arise out of a chilly sense of what is due to them, but out of a celebratory feeling that there is always more to be discovered. ${ }^{19}$

Both novelist and cleric - along with many bicentennial commentators - have found common ground in the idea that Dickens is, and should be, a visceral experience: something 'in the blood', something that must be felt, something that in its emotional intensity can be transformative. Professor Julius Grey described this phenomenon as 'transcendental' in a bicentennial article for the Montreal Gazette. Grey recounts how as a young, desperately unhappy boy recently arrived in a foreign country he came across 'a $19^{\text {th }}$-century Polish translation of David Copperfield' and was 'transfixed'. After three days' total immersion in the 'moments of terrible sadness and [...] total exhilaration', Grey describes himself as emerging 'a different boy, reconciled [...] and more mature': '[David's] comeback [had] awakened in me an optimism that had almost disappeared. ${ }^{20}$

Yet, as we celebrate the bicentenary, should we also be asking what effect - to borrow Philip Womack's recent formulation — such a 'deep, peculiar hold upon us' has on our readings, on our perception of Dickens's intentions, and how this influences what we celebrate $?^{21}$ How much would Dickens have recognized himself in Dr Williams's insistence that a 'generous embrace' of humanity superseded any cerebral 'chilly sense' of what is due? Would he have recognized the idea that he 'loves the poor and destitute, not from a sense of duty but from a sense of outrage that their lives are being made flat and dead'? ${ }^{22}$ And what response might he have had to the idea - intended by one commentator as a compliment - that no one 'should be forced to read the man for any other reason than to indulge in the sheer pleasure and richness of his language and characters' ${ }^{23}$ Perhaps it is precisely the task of dwelling in just such a morally complex 'space' between emotional 'generous embrace' and the intellect's 'chilly sense of what is due' that Dickens had in mind for us?

At the 1912 centenary the Manchester Guardian expressed concern with an overly simplistic response to Dickens, lamenting that 'the hackneyed dictum of our time is that purpose has gone out of fiction, and that the sole concern is life and character without any further preoccupation'. ${ }^{24}$ Thus commentators one hundred years ago were beginning to be concerned about the potential of readers' over-investment in 'character' which obscured the novels' social content. Marking a 'centenary [that] is assuredly but the first in a series' Richard Whiteing already felt compelled to appeal for recognition of the dual presence of emotional 'life' and ethical 'purpose' in Dickens's work: 
His great art lay in his being able to take causes as the source [...] and at the same time make them vital by means of a perfect feeling for nature and life. From beginning to end it was always a cause. ${ }^{25}$

Recent scholars have argued that any 'visceral' reaction was only the initial stage of the nineteenth-century emotional sympathetic response. ${ }^{26}$ Thus as we twenty-first-century Dickens readers process into the 'Bicentennial Abbey', do we do Dickens a disservice to focus solely on the 'celebratory feeling' of our own emotional responses? Would he not have also wanted us to read his works again, look around the Abbey's wider city, and consider how many modern Olivers might still exist today? ${ }^{27}$ Therefore, while still allowing ourselves to 'feel' the often intense emotional power of Dickens's writing, must we not also remember as well his plea to ensure we are able to say:

I have thought of this. I have not dismissed the thing. I have neither blustered it away, nor frozen it away, nor tied it up and put it away, nor smoothly said pooh, pooh! to it when it has been shown to me. ${ }^{28}$

\section{What's the Point of Dickensian Feeling in 2012? Holly Furneaux}

Oscar Wilde, who famously chuckled at the death of Little Nell, was more seriously sceptical about Dickensian sentiment, even (and especially!) when it put feeling in the service of social change: 'Charles Dickens was depressing enough in all conscience when he tried to arouse our sympathy for the victims of the poor-law administration.' Wilde did not see social reform as the business of the novelist as an aesthetic artist, and he placed 'partisan feeling' and that which 'appeals strongly to our sympathies' 'outside the proper sphere of art'. ${ }^{29}$ This is rather a different critique to that levelled against an eighteenthcentury tradition of luxurious sentiment, which allowed men and women 'of feeling' to experience exquisite, perhaps cathartic, sympathy — for, say, a poor invalided soldier and then to continue their daily lives having done nothing to relieve him or others similarly suffering. Both lines of criticism suggest the problems of any simple celebration of an author's ability to provoke emotional response, and there has long been a critical scepticism around Dickensian sentiment. ${ }^{30}$ So should we be wary of the high content of emotion apparent in bicentenary responses to Dickens? Does the power of Dickensian feeling signal bad art and bad politics? 
As these pieces show, felt response, often of a style recognizable from Victorian responses to Dickens, has been a notable characteristic of this bicentenary. ${ }^{31}$ In a festive piece for $i$ paper at the end of 2011, author Justin Cartwright described his sense of Christmas as a time of 'compassion and the feeling of being in some way more human', having 'acquire[d]' 'these feelings from reading Dickens.' He spoke of Dickens as one of the first writers he 'got to know well' as a boy in South Africa. Cartwright goes on from a sense of personal acquaintance to a familial feeling for Dickens, using the fiction as a lens through which to understand his own relatives: 'My father was something of a Dickensian character himself, good hearted but inept. ${ }^{, 32}$

Cartwright's responses continue a long tradition of emotional intimacy with Dickens, in which his characters are felt to be part of one's own domestic circle. Amy Cruse's 1935 study of The Victorians and their Books includes numbers of firsthand accounts of family life understood via the characters and structures of Dickens's fiction. She cites, for example, Francis Barnard's perception of his nursery governess as 'a Cornelia Blimber' and his description of his severe childhood illness as a time when he 'acted Paul Dombey to the life'. ${ }^{33}$ Barnard's and Cartwright's imaginative identification of Dickens in their lives suggests the ways in which an experience of Dickensian feeling can be used to process and articulate ambivalent sentiment. Barnard's reference to Paul Dombey in order to express his early sense of the proximity of death, and Cartwright's reference to the mixed 'Dickensian' characteristics of his father, do not suggest any simple catharsis through feeling Dickens. Rather, they point to a more complicated emotional legacy engendered by Dickens's aspiration to be represented at every hearthside. The creative application of this idea, through which — often difficult — domestic experience can be understood and expressed via Dickens, suggests an intimate and imaginative value to emotional engagement with this author, of a different kind to that luxurious sentiment which is detrimental (so the critiques go) both to politics and to art.

As the bicentenary teaches us that feeling continues to be a characteristic mode of response to Dickens, our challenge is to understand the impetus for such intense emotional reaction, and to explore the potentially productive purposes that it might serve. In documenting the complexity of Dickensian feeling produced this year, these pieces suggest that a combination of scepticism and celebration is needed for navigating the powerful emotional currents of 2012. 
${ }^{1}$ Armando's Tale of Charles Dickens (BBC, 2012) <http://www.bbc.co.uk/programmes/b0195pt7> [accessed 20 March 2012].

2 Peter Parley's Penny Library (1841), quoted in Charles Dickens: The Critical Heritage, ed. by Philip Collins (London: Routledge, 2005), p. 5.

3 'In and on an Omnibus', All the Year Round (21 January 1865), p. 567.

4 'Shakespeare-Mad', All the Year Round (21 May 1864), p. 351.

5 'Shakespeare-Mad', p. 346.

${ }^{6}$ Charles Dickens, Our Mutual Friend (London: Penguin, 1997), p. 18.

${ }^{7}$ Armando's Tale of Charles Dickens.

${ }^{8}$ Simon Callow, 'My Hero: Charles Dickens', Guardian, 4 February 2012

$<$ http://www.guardian.co.uk/books/2012/feb/04/my-hero-charles-dickens-callow> [accesssed 27 April 2012].

${ }^{9}$ Clare Allan, 'The Coalition's Dickensian Take on Disability Allowance', Guardian, 3 January 2012 $<$ http://www.guardian.co.uk/society/2012/jan/03/coalition-abolishing-disability-living-allowance $>$ [accessed 27 April 2012].

${ }^{10}$ Martin Rowson, 'Martin Rowson on the Return to Dickensian times - Cartoon', Guardian, 7 February $2012<$ http://www.guardian.co.uk/commentisfree/cartoon/2012/feb/07/martin-rowson-charles-dickens $>$ [accessed 27 April 2012].

${ }^{11}$ Allison Pearson, 'Let's Give Our Children Great Expectations', Telegraph, 8 February 2012 $<$ http://www.telegraph.co.uk/education/9069240/Lets-give-our-children-great-expectations.html $>$ [accessed 27 April 2012]

${ }^{12}$ Peter Conrad, 'The Selected Letters of Charles Dickens edited by Jenny Hartley; Charles Dickens and the Great Theatre of the World by Simon Callow - Review', Guardian, 26 February 2012 $<$ http://www.guardian.co.uk/books/2012/feb/26/letters-dickens-hartley-theatre-callow-review $>$ [accessed 27 April 2012].

${ }^{13}$ Dickensian, 8 (1912), p. 59.

${ }^{14}$ J. Cuming Walters, 'Our Year of Preparation', Dickensian, 7 (1911), pp. 5-6.

15 'The Dickens Centenary: A Proposed Novel Scheme', Dickensian, 6 (1910), pp. 229-32.

16 'The Dickens Centenary Register', Dickensian, 7 (1911), pp. 184-85.

${ }^{17}$ See $<$ http://literature.britishcouncil.org/news/2012/january/readathon $>$ [accessed 27 April 2012].

${ }^{18}$ Howard Jacobson, 'Dickens is Proof that Humour Improves with Age', Independent, 11 February 2012, p. 44.

${ }^{19}$ Rowan Williams, 'Archbishop's Address at the Wreath Laying Ceremony for Charles Dickens'. Taken from a press release (which includes full text of the address) issued by the office of the Archbishop of Canterbury and carried by States News Service, 7 February 2012.

${ }^{20}$ Julius Grey, 'In Dickens, a Way Forward', Montreal Gazette, 11 February 2012, p. 3. 
${ }^{21}$ Phillip Womack, 'Why Charles Dickens Speaks to Us Now',

$<$ http://www.telegraph.co.uk/culture/books/9066463/why-charles-dickens-speaks-to-us-now.html> [accessed 27 April 2012].

${ }^{22}$ Williams, 'Archbishop's Address'.

23 Lynne Roberts, 'A Wisdom of the Heart', Sunday Times (South Africa), 12 February 2012 $<$ http://www.timeslive.co.za/lifestyle/books/2012/02/12/a-wisdom-of-the-heart $>$ [accessed 27 April 2012].

${ }^{24}$ Richard Whiteing, 'Charles Dickens. Feb. 7 1812: June 9, 1870 - The Man and His Work', Manchester Guardian, 7 February 1912, p. 5. < http://archive.guardian.co.uk/Repository/ml.asp?Locale=english-skincustom\&Mode=GIF\&Ref=R1VBLzE5MTIvMDIvMDcjQXIwMDUwMg $>$ [accessed 27 April 2012].

${ }^{25}$ Whiteing, 'Charles Dickens', p. 5.

${ }^{26}$ See, for example, D. Rae Grainer, 'Thinking of Me Thinking of You: Sympathy Versus Empathy in the Realist Novel', Victorian Studies, 53.3 (2011), 417-26.

${ }^{27}$ The Times website ranked Dickens as the tenth most important person to watch in 2012, remarking that 'The images of poverty and crime in Oliver Twist deeply shocked his Victorian audience. Two hundred years later, Dickens might walk around some of the most deprived parts of Britain and wonder how much has changed.' (see 'The Times 100 to Watch in 2012: Interactive' <http://www.thetimes.co.uk>, 20 January 2012 [accessed via Nexis, 7 March 2012].

${ }^{28}$ Charles Dickens, 'On Duty with Inspector Field', in The Works of Charles Dickens, Gadshill Edition (London: Chapman and Hall, n.d.), XXXIV: Reprinted Pieces, 176.

${ }^{29}$ Oscar Wilde, 'The Decay of Lying', repr. in The Decay of Lying and Other Essays (London: Penguin, 2003), pp. 1-38 (pp. 13-14).

${ }^{30}$ See the discussions in Rethinking Victorian Sentimentality, ed. by Nicola Bown (= 19: Interdisciplinary Studies in the Long Nineteenth Century, 4 (2007)).

${ }^{31}$ I have spoken more about the range of felt responses to Dickens in a bicentenary blog post for Cambridge University Press. See <http://www.cambridgeblog.org/2011/12/dickens-in-2012-why-his-writing-matters200-years-later-holly-furneaux/> [accessed 27 April 2012].

${ }^{32}$ Justin Cartwright, 'God Bless This Merry Gentleman', a piece to accompany the BBC Radio 3 series The Essay: The Writer's Dickens, in i, 21 December 2011, pp. 36-37.

${ }^{33}$ Amy Cruse, The Victorians and Their Books (London: Allen and Unwin, 1935), p. 171. 